\title{
Implications of Genetically Modified Food Technology Policies for Sub-Saharan Africa
}

\author{
Kym Anderson (World Bank, CEPR and University of Adelaide) and \\ Lee Ann Jackson (WTO Secretariat, Geneva)
}

\author{
Contact author: \\ Kym Anderson \\ Development Research Group \\ The World Bank \\ 1818 H Street NW \\ Washington DC 20433 USA \\ Phone +1 2024733387 \\ Fax +12025221159 \\ kanderson@worldbank.org
}

World Bank Policy Research Working Paper 3411, September 2004

The Policy Research Working Paper Series disseminates the findings of work in progress to encourage the exchange of ideas about development issues. An objective of the series is to get the findings out quickly, even if the presentations are less than fully polished. The papers carry the names of the authors and should be cited accordingly. The findings, interpretations, and conclusions expressed in this paper are entirely those of the authors. They do not necessarily represent the view of the World Bank, its Executive Directors, or the countries they represent. Policy Research Working Papers are available online at http://econ.worldbank.org.

Kym Anderson is Professor of Economics at, but on leave from, the University of Adelaide, and is now Lead Economist (Trade Policy) in the Development Research Group of the World Bank in Washington DC. Lee Ann Jackson is with Agriculture Division of the WTO Secretariat in Geneva. This paper was first drafted while both were with the Centre for International Economic Studies at the University of Adelaide. We acknowledge with thanks funding support from Australia's Rural Industries Research and Development Corporation and the Australian Research Council, and helpful comments from referees. 


\begin{abstract}
The first generation of genetically modified (GM) crop varieties sought to increase farmer profitability through cost reductions or higher yields. The next generation of GM food research is focusing also on breeding for attributes of interest to consumers, beginning with 'golden rice', which has been genetically engineered to contain a higher level of vitamin A and thereby boost the health of unskilled laborers in developing countries. This paper analyzes empirically the potential economic effects of adopting both types of innovation in Sub-Saharan Africa (SSA). It does so using the global economy-wide computable general equilibrium model known as GTAP. The results suggest that the welfare gains are potentially very large, especially from nutritionally enhanced GM rice and wheat, and that - contrary to the claims of numerous interests those estimated benefits are diminished only slightly by the presence of the European Union's current barriers to imports of GM foods. In particular, if SSA countries impose bans on GM crop imports in an attempt to maintain access to EU markets for non-GM products, the loss to domestic consumers due to that protectionism boost to SSA farmers is far more than the small economic gain for those farmers from greater market access to the EU.
\end{abstract}

JEL codes: C68, D58, F13, O3, Q17, Q18

Key words: Biotechnology, GMOs, trade policy, regulation, computable general equilibrium, Sub-Saharan Africa 


\section{Implications of GM Food Technology Policies for Sub-Saharan Africa}

\section{Introduction}

Over the 13,000 years since humankind began to move beyond just hunting and gathering, one of the most important micro contributors to economic progress has been innovation in food production (Diamond 1998). Even as recently as the period since 1960, the world has seen a major example of that in the so-called 'green revolution'. That revolution initially brought higher-yielding semi-dwarf wheat and rice varieties to vast areas of Asia and other developing regions that had access to irrigation or reliable rainfall, but then extended to include the adoption of modern varieties of numerous other grains, root crops and protein crops. The adaptation of modern varieties to local conditions by national scientists and farmers' subsequent gradual adoption of those varieties were by no means uniform. In particular, Africa lagged far behind Asia and Latin America, contributing importantly to that continent's relatively slow growth in per capita food production particularly up to the 1990s (Evenson and Gollin 2003). Given that Africa now accounts for one-third of the world's people living on less than $\$ 1$ a day (up from one-tenth two decades ago - Chen and Ravallion 2004), and that the vast majority of poor people in Sub-Saharan Africa are dependent on agriculture for their livelihood and much of their food, this has been an opportunity lost for a whole generation for hundreds of millions of people.

In the latter 1990s, another agricultural revolution began, this time involving biotechnology including genetic modification (the so-called gene revolution). Genetically 
modified (GM) crops have great potential for farmers and ultimately consumers. Benefits for producers could include greater productivity and less occupational health and environmental damage (e.g., fewer pesticides), while benefits to consumers could include not only lower food prices but also enhanced attributes (e.g., 'nutriceuticals'). While traditional biotechnology improves the quality and yields of plants and animals through, for example, selective breeding, genetic engineering enables direct manipulation of genetic material. In this way the new GM technology has the potential to accelerate the development process by shaving years off $R \& D$ programs. Protagonists argue that genetic engineering also entails a more controlled transfer of genes because the transfer is limited to a single or just a few selected genes, whereas traditional breeding risks transferring unwanted genes together with the desired ones.

This new agricultural biotechnology has been adopted very rapidly where it has been allowed to flourish, but to date that is in just a handful of countries (most notably the United States, Canada and Argentina) and so involves only their most important crops (namely maize, soybean and canola) plus cotton. ${ }^{1}$ GM varieties of wheat, rice and other food crops would be ready for release were it not for opposition to GM technology by vocal consumer and environmental groups, particularly in Western Europe, concerned about the GM crops' potentially adverse impacts on food safety (e.g., 'Will they cause cancer?') and the environment (e.g., 'Will they lead to herbicide-resistant superweeds?'). The EU responded to pressure from these groups in October 1998 by placing a de facto moratorium on the production and use of GM varieties other than the tiny number

\footnotetext{
${ }^{1}$ China and a few other countries including South Africa also have adopted GM cotton. That crop is ignored in what follows since the focus of this paper is on food.
} 
approved to that date. Since April 2004, that moratorium has been replaced by GM labeling laws that are so strict as to have almost the same restrictive effect on trade.

As a result of the EU de facto moratorium, the United States share of the EU's maize imports has fallen to virtually zero (from around two-thirds in the mid-1990s, close to the United States share of world exports), as has Canada's share of EU canola imports (from 54 percent in the mid-1990s). The fall has been less dramatic in the case of soybean products, but in all three cases the GM-adopting countries have lost market share to GM-free suppliers. As a consequence, countries exporting food products fear that they will find food-importing countries discounting or denying access to their products if their farmers adopt GM technology or even if they import GM food (because of the risk of contamination of domestically produced non-GM food).

This new biotechnology therefore raises a number of dilemmas for African countries. Will the resulting decline in international food prices raise or lower national economic welfare in Africa (e.g., because they are net importers or exporters of food)? If the EU were to retain its barriers to imports of GM food, would African food exporters gain more from reduced competition in that market than from trying to develop and adopt new GM crop varieties? If that improved competitiveness required in turn a ban on imports of all food and feed from GM-adopting countries by those African countries so as to avoid contamination (as ostensibly feared by Mozambique, Zambia and Zimbabwe when they were offered food aid from the United States in 2002), would the domestic economic loss to net buyers of food outweigh the gains to farmers in those countries? How would a country's welfare be affected if a neighboring country (e.g., South Africa) chose to adopt GM varieties of key foods? 
This paper attempts to address these empirical questions. It does so by using a well-received simulation model of the global economy known as GTAP, in which the South African Customs Union (SACU), the other members of the Southern African Development Community (SADC), and the rest of Sub-Saharan Africa are among the separately identified regions. ${ }^{2}$ The model's base simulation, calibrated to 1997 just before the EU de facto moratorium was imposed, is compared with a series of alternative scenarios. After discussing the results and key caveats including the practicality of GM adoption in Africa, the paper concludes by drawing out welfare and poverty implications for Sub-Saharan African countries under various trade and technology policy scenarios.

\section{Model methodology}

We use a well-received empirical model of the global economy (the GTAP model) to examine the effects of some countries adopting the new GM technology without and with government and consumer responses in other countries. Being a general equilibrium model, GTAP (Global Trade Analysis Project) describes both the vertical and horizontal linkages between all product markets both within the model's individual countries and regions as well as between countries and regions via their bilateral trade flows. The GTAP Version 5.4 database used for these applications draws on the global economic structures and trade flows of 1997, an ideal year as it is the time of the take-off in adoption of GM crop varieties and the year prior to the EU's adoption of it de facto moratorium. To make the results easier to digest, the GTAP model has been aggregated

\footnotetext{
${ }^{2}$ SACU comprises South Africa plus Botswana, Lesotho, Namibia and Swaziland. In addition to those five, the Southern African Development Community (SADC) comprises Angola, Democratic Republic of Congo, Malawi, Mauritius, Mozambique, Seychelles, United Republic of Tanzania, Zambia and Zimbabwe. The rest of Sub-Saharan Africa comprises all other countries in the continent except the following North African ones: Algeria, Egypt, Libya, Morocco and Tunisia.
} 
to depict the global economy as having 17 regions and 14 sectors (with the focus on the primary agricultural sectors affected by the GM debate and their related processing industries). ${ }^{3}$ We have undertaken further sectoral disaggregation of the database by separating golden rice $^{4}$ and other GM crop varieties from non-GM varieties of rice, oilseeds, coarse grains and wheat. There are five types of productive factors in the version of the GTAP model used here: skilled labor, unskilled labor, agricultural land, other natural resources, and other (non-human) capital. All factors except natural resources (which are specific to primary production) are assumed to be perfectly mobile throughout the national economy but immobile internationally.

We have modified the GTAP model so it can capture the effects of productivity increases of GM crops, consumer aversion to consuming first-generation GM products, and substitutability between GM and non-GM products as intermediate inputs into final consumable foods.

The simulations use a standard, neoclassical GTAP closure. This closure is characterized by perfect competition in all markets, flexible exchange rates and fixed endowments of labor, capital, land and natural resources. One outcome of this specification is that wages are flexible and the labor (and other factor) markets operate at

\footnotetext{
${ }^{3}$ The GTAP (Global Trade Analysis Project) model is a multi-regional, static, applied general equilibrium model based on neo-classical microeconomic theory assuming perfect competition, constant returns to scale and full employment of all productive factors which are immobile internationally. International goods and services trade is described by an Armington specification, which means that products are differentiated by country of origin. See Hertel (1997) for comprehensive model documentation and Dimaranan and McDougall (2002) for details of the GTAP 5.4 database used here. The model is solved with GEMPACK software (Harrison and Pearson 1996). Welfare decomposition follows Harrison, Horridge and Pearson (1999). Previous uses of the GTAP model in assessing the economic implications of GM crop adoption include Nielsen and Anderson (2001), van Meijl and van Tongeren (2002), Jackson and Anderson (2003) and Huang et al. (2004).

${ }^{4}$ Golden rice is a GM variety that may have no farm productivity attributes but has the potential to improve health significantly in regions where rice is or could be a dietary staple for poor people, through providing pro-vitamin A. The latter characteristic is the result of golden rice being genetically engineered to contain a higher level of beta-carotene in the endosperm of the grain. See Ye et al. (2000) and Beyer et al. (2002).
} 
full employment. In addition, investment funds are re-allocated among regions following a shock so as to return to equalized expected rates of return.

\section{Production}

Traditionally, to distinguish GM from non-GM productivity, outputs of the GMadopting sectors are each sub-divided into GM and non-GM product. Except for golden rice, an output-augmenting, Hicks-neutral productivity shock is implemented on the GM varieties of these commodities to capture their higher farm productivity. ${ }^{5}$ This assumes that GM technology uniformly reduces the level of primary factors needed per unit of food crop output. When a region does not adopt GM technologies, no regional factor productivity shock is included and there is no distinction between GM and non-GM production in these regions. In the constant-elasticity-of-substitution production nest, producers choose first between imported and domestic inputs according to the model's Armington (1969) elasticities, and then choose whether or not to use GM or non-GM intermediate inputs in their production of final goods.

However, as discussed in more detail elsewhere (Anderson, Jackson and Nielsen 2004), second-generation GM varieties such as golden rice require a treatment different from first-generation GM varieties. We assume there is no net difference between producing second-generation GM crops and their non-GM counterpart in terms of farm productivity: any input saving is assumed to be absorbed in the cost of segregation and identity preservation. The motivation for developing country farmers to adopt nutritionally enhanced varieties has to come from their higher valuation in the domestic

\footnotetext{
5 This is an improvement over earlier work by ourselves (e.g. Anderson and Nielsen 2001; Nielsen and Anderson 2001) and others where all production was assumed to switch to GM varieties in the adopting countries.
} 
market in competition with other GM and traditional varieties, net of the extra cost of segregation and identity preservation of these superior varieties when they are marketed outside the farm household.

Data on global adoption of GM technologies reveal a wide divergence in adoption across countries. In the first simulation, we assume that 75 percent of oilseed production in the United States, Canada and Argentina is GM and that 45 percent of United States and Canadian and 30 percent of Argentinean rice, wheat and coarse grain production is GM. (Since these countries are already GM adopters in coarse grain and oilseeds, we assume they would also be the earliest adopters of GM rice and wheat once they are ready for commercial release. Those countries' farmers have shown no interest in golden rice, so it is assumed their adoption is restricted to other GM rice varieties.) In the scenarios involving GM rice adoption in developing countries, we consider two cases: one in which 45 percent of the rice crop is grown with GM seed that enhances farm productivity, and the other in which 45 percent of the rice crop uses golden rice seed. The latter set of adopting farmers is assumed to be able to segregate their golden rice from other rice in order to market this product based on its enhanced nutritional composition. ${ }^{6}$ We also consider a case where some developing countries adopt GM varieties of coarse grains, oilseeds and wheat that are assumed to account for 45 percent of their production of those crops.

\footnotetext{
${ }^{6}$ The cost of segregation would be smaller, the more rice is consumed by the producing household or sold to local consumers, as is common in developing countries. This situation is thus qualitatively different from that analyzed by Lapan and Moschini (2004) where the costs of segregation and identity preservation are assumed to be significant.
} 


\section{Productivity shocks}

The simulations assume GM technical change in grain and oilseed production is Hicks-neutral, involving an output-augmenting productivity shock of 7.5 percent for coarse grain, 6 percent for oilseeds and 5 percent for wheat and rice (Table 1). Alternative simulations were conducted to assess the importance of altering these assumptions to allow for biased technical change, but because the welfare results are not substantially different we retained the simpler Hicks-neutral assumption. ${ }^{7}$ The productivity growth is assumed to be net of the higher cost of GM seed and the altered cost of such things as pesticides. ${ }^{8}$

While GM rice and wheat has not yet been commercialized, around the world several varieties have been approved for field trials and environmental release. A recent study found that, even under conservative adoption and consumption assumptions, introducing golden rice in the Philippines could decrease the number of disabilityadjusted life years (DALYs) lost due to Vitamin A deficiency by between 6 and 47 percent (Zimmermann and Qaim 2003). That is equivalent to an increase in unskilled labor productivity of up to 0.53 percent. Based on those findings, Anderson, Jackson and Nielsen (2004) represent these health impacts with an assumed 0.5 percent improvement in unskilled labor productivity in all sectors of golden rice-adopting Asian developing

\footnotetext{
${ }^{7}$ Because it makes little difference to the results being analysed here, we simply follow previous analysts in assuming that the productivity effects of genetic modification do not differ across inputs (Nielsen and Anderson (2001), Anderson, Nielsen and Robinson (2002)). For studies that differentiate the degrees of factor/input saving, see van Meijl and van Tongeren (2002) and Huang et al. (2004).

${ }^{8}$ The concern that risk-averse poor farmers would be unable to afford to take up the higher cost of GM seeds provided by private biotech firms does not seem to be vindicated by the dramatic take-up of GM cotton in developing countries as soon as it is available and can be seen to be profitable. On the adoption experience in China and India, for example, see Pray et al. (2003) and Pray, Bengali and Ramaswami (2004). Part of the reason for that rapid uptake in developing countries may be because of the occupational health benefits for farmers, who expose themselves to fewer chemical pesticides with GM cotton (Hossain et al. 2004), but mainly it is because of its much greater productivity (FAO 2004, Table 7).
} 
economies. Given the low nutrition levels of poor workers in Africa, and the fact that if golden rice were to be adopted in Asia and Africa then nutritionally enhanced GM varieties of wheat and other foods would soon follow, we assume the productivity of unskilled labor would rise by 2 percent following adoption of second-generation GM crops. We also assume no direct impact on the productivity of skilled laborers, who are rich enough to already enjoy a nutritious diet. ${ }^{9}$ And to continue to err on the conservative side, we assume second-generation GM crop varieties are no more productive in the use of factors and inputs than traditional varieties net of segregation and identity preservation costs, even though there is evidence to suggest they may indeed be input-saving. ${ }^{10}$

\section{Consumption}

In order to capture consumer aversion to GM products in OECD countries, elasticities of substitution between GM and non-GM products in those regions are set at low levels. ${ }^{11}$ Once nutritionally enhanced GM grain varieties are introduced, consumers in Sub-Saharan Africa are assumed to have a preference for them over their traditional counterparts. For simplicity and to continue to be conservative, we ignore the possibility that consumers of inferior grains might shift to these new grains and instead just represent the consumer response as involving demand for traditional rice or wheat shrinking by 45

\footnotetext{
${ }^{9}$ There would also be non-pecuniary benefits of people feeling healthier, and less expenditure on health care, but these too are ignored so as to continue to err on the conservative side. For more on this and other aspects of golden rice and other biotech R\&D outcomes, see Conway (2003).

${ }^{10}$ Bouis (2002) and Welch (2002) suggest nutritionally enhanced rice and wheat cultivars are more resistant to disease, their roots extend more deeply into the soil so they require less irrigation and are more drought resistant, they release chemical compounds that unbind trace elements in the soil and thus require less chemical inputs, and their seeds have higher survival rates.

${ }^{11}$ Elasticities of substitution are included in the computation of the distribution of GM and non-GM consumption of coarse grains, oilseeds, wheat and rice within each region. Systematic sensitivity analysis indicates that varying the elasticities of substitution for these commodities has minimal impact on the model solution. Again, details are available from the authors.
} 
percent so that the nutritionally enhanced variety accounts for 45 percent of total demand for that cereal in adopting countries. And we assume the consumer health benefits of second-generation GM varieties are confined to the adopting countries.

\section{Scenarios}

The base simulation in the GTAP model, which is calibrated to 1997 , is compared with four sets of simulations. The first set examines the effects of adoption of currently available GM varieties of maize, soybean and canola ${ }^{12}$ by the current adopters (Argentina, Canada and the United States) without and then with the EU de facto moratorium on GMOs in place, before examining what impact adoption in South Africa would have, and then the benefits from adoption elsewhere in Africa, and then in the rest of the world as well:

Sim 1a: The United States, Canada and Argentina adopt GM varieties of coarse grain and oilseeds that raise farm productivity there

Sim 1b: As for Sim 1a + the EU bans imports of those crops from GM-adopting countries Sim 1c: As for Sim 1a + SACU adopts GM varieties of coarse grain and oilseeds Sim 1d: As for Sim 1b + SACU adopts GM varieties of coarse grain and oilseeds Sim 1e: All countries adopt GM varieties of coarse grain and oilseeds.

\footnotetext{
${ }^{12}$ This has to be done in a slightly inflating way in that the GTAP model is not disaggregated below 'coarse grains' and 'oilseeds'. However, in the current adopting countries (Argentina, Canada and the US), maize, soybean and canola are the dominant coarse grains and oilseed crops.
} 
The second set of simulations involves a repeat of the first set except that China and India are assumed to join America in adopting, and GM (non-golden) rice and wheat are assumed to be made available to those adopting countries' farmers:

Sim 2a: The United States, Canada and Argentina plus China and India adopt GM varieties of coarse grain, oilseeds, rice and wheat (without EU moratorium)

Sim 2b: As for Sim 2a + the EU bans imports of those crops from GM-adopting countries Sim 2c: As for Sim 2a + SACU adopts GM varieties of coarse grain, oilseeds, rice and wheat

Sim 2d: As for Sim $2 b+$ SACU adopts GM varieties of coarse grain, oilseeds, rice and wheat

Sim 2e: All countries adopt GM varieties of coarse grain, oilseeds, rice and wheat.

The third set of simulations focuses on what difference it would make if SADC countries other than SACU members either banned imports of GM varieties or allowed their farmers and consumers access to them:

Sim 3a: As for Sim 1d + Rest of SADC also bans imports of those crops from GMadopting countries

Sim 3b: As for Sim 2d + Rest of SADC also bans imports of those crops from GMadopting countries

Sim 3c: As for Sim 2d + Rest of SADC adopts GM varieties of coarse grain, oilseeds, rice and wheat. 
Finally, the fourth set of simulations repeats some of the second set except the GM rice and wheat is nutritionally enhanced and so it boosts all unskilled labor productivity in Sub-Saharan Africa by 2 percent instead of boosting just farm productivity:

Sim 4a: As for 2a + Sub-Saharan Africa adopts second-generation GM rice and wheat that enhances health and thereby the productivity of unskilled labor in the region $\operatorname{Sim} 4 \mathrm{~b}$ : As for $4 \mathrm{a}+$ the EU bans imports of those crops from GM-adopting countries.

These simulations, which are summarized in Table 2 , are clearly only a small subset of possible simulations, but they are chosen to illustrate the main choices facing Sub-Saharan Africa.

\section{Results}

The estimated national economic welfare effects of the first set of these shocks are summarized in Table 3. Assuming no adverse reaction by consumers or trade policy responses by governments, the first column shows that the adoption of GM varieties of coarse grains and oilseeds by the United States, Canada and Argentina would have benefited the world by almost US $\$ 2.3$ billion per year, of which $\$ 1.3$ billion is reaped in the adopting countries while Asia and the EU enjoy most of the rest (through an improvement in their terms of trade, as net importers of those two sets of farm products). The only losers in that scenario are countries that export those or related competing 
products. Australia and New Zealand lose slightly (not shown in Table 3) because their exports of grass-fed livestock products are less competitive with now-cheaper grain-fed livestock products in GM-adopting countries. But so too do the non-SADC countries of Sub-Saharan Africa as a group, although again only slightly. South Africa gains slightly as a net importer of coarse grains and oilseeds, while the net welfare effect on the rest of SADC is negligible.

Column 2 of Table 3 shows the effects when the EU's moratorium is taken into account. The gains to the adopting countries are one-third less, the EU loses instead of gains (not accounting for the value EU consumers place on being certain they are not consuming food containing GMOs), and the world as a whole would be worse off (by $\$ 1.2$ billion per year, instead of better off by $\$ 2.3$ billion, a difference of $\$ 3.5$ billion) because the gains from the new technology would be more than offset by the massive increase in agricultural protectionism in the EU due to its import restrictions on those crops from GM-adopting American countries. For SSA, however, welfare would be greater than in Sim 1a because in Sim 1b African farmers are able to sell into the EU with less competition from the Western Hemisphere. The extra benefit is very small though, at just $\$ 20$ million p.a.

Columns 3 and 4 of Table 3 are the same as columns 1 and 2 except that SACU is assumed also to adopt GM coarse grains and oilseeds. In the absence of the EU moratorium this decision to adopt GM varieties of those crops, given their assumed farm productivity effects, would benefit SACU an extra $\$ 6$ million p.a. while helping the rest of SSA by an extra $\$ 1$ million (compare Sims 1a and 1c). However, in the presence of the EU ban, SACU would be \$2 million worse off and the rest of SSA \$3 million better off 
(compare Sims $1 b$ and $1 d$ ). SACU is worse off while the EU moratorium is in place because it is denied market access once it decides to adopt GM varieties. That makes more room for exports from the rest of SSA to the EU (assuming they can continue to meet EU import standards despite possibly importing GM varieties from SACU), as well as providing the rest of SSA with lower-priced food imports from SACU, which is why those countries are better off under the moratorium when SACU adopts.

Column 5 of Table 3 assumes the world relaxes about GMOs and all countries adopt the technology for coarse grains and oilseeds. Global welfare in that case is almost double what it is with just the current three adopters (compare with Sim 1a). South Africa's welfare is the same in this as in Sim 1c, because it so happens that its terms of trade change hardly at all with the rest of the world now adopting. Welfare in the rest of SSA, however, is enhanced considerably (by $\$ 46$ million p.a. compared with the current situation as depicted in Sim 1b) and, as a proportion of GDP, those economies gain three to four times as much as SACU (see final column of Table 3). They gain because of the boost to the productivity of their farms provided by the GM varieties, and despite a deterioration in their terms of trade.

The above numbers are small, but recall they refer to adoption only of GM varieties currently in production. If GM rice and wheat adoption also were to be allowed, global welfare would be increased by nearly twice as much (compare bottom right-hand corners of Tables 4 and 3: $\$ 7.5$ versus $\$ 4.0$ billion), because world markets for those two crops are even larger than for coarse grains and oilseeds. Again, though, SSA economies would gain little if they do not participate, with the benefit in terms of enhanced competitiveness from abstaining in the presence of the EU moratorium being very minor 
relative to the foregone productivity benefits from adopting the new technology. ${ }^{13} \mathrm{SACU}$ is \$4-6 million better off when rice and wheat are included, mainly because of its improved terms of trade (being an importer of those products) but also from its own farmers' greater productivity boost when they are allowed to adopt these additional GM varieties. The extra benefit for the rest of SADC and the rest of SSA through improved terms of trade from SACU's adoption in the presence of the EU moratorium is just \$7-11 million p.a. (even if they could maintain their GM-free status at no cost following SACU's adoption), compared with an extra gain of $\$ 121$ million from the greater boost to farm productivity if those regions also were to join the rest of the world in allowing adoption of this broader range of GM varieties (shown later as the difference between scenarios $2 \mathrm{e}$ and $1 \mathrm{e}$ in Table 8 below).

The above scenarios assume the export sales to the EU by SSA countries other than SACU would not be affected by SACU's adoption of GM varieties. It is possible that, because of accidental contamination from seed imported from SACU, some of the other SSA countries could lose their GM-free status if SACU adopted GM varieties (or if GM varieties were imported from other adopters such as the United States, as might have happened via food aid in 2002). In an attempt to avoid this, SADC members other than SACU may place a ban on imports of these products from GM-adopting countries. The welfare effects of such action can be seen in Table 5 where, in Sims $3 a$ and $3 b$, the rest of SADC bans imports of the affected crops from GM-adopting countries, while in Sim 3c it instead embraces the technology along with SACU. In Sims 3a and 3b, SACU is made

\footnotetext{
${ }^{13}$ In this as in all the simulations, there is an implicit assumption that, if government policies allowed, the technology would be developed by biotech corporations for each of the regions concerned and the GM seed varieties would be made available for purchase by adopting farmers to provide the net farm productivity gains reported in Table 1. Those seed firms are too small a fraction of the global economy to include as a separate sector in the model. The assumed productivity gains are net of the higher price of GM seed.
} 
slightly worse off relative to Sims $1 \mathrm{~d}$ and $2 \mathrm{~d}$ (by $\$ 3-4$ million p.a., depending on whether GM rice and wheat also are adopted), while the rest of SADC is hurt even more (by \$514 million p.a.) assuming consumers there are indifferent to consuming food that may contain GMOs, while welfare of other SSA countries remains virtually the same. By contrast, if the rest of SADC were to adopt GM varieties of all four sets of crops along with SACU, as in Sim 3c, its welfare would be boosted by $\$ 26$ million instead of reduced by $\$ 10$ million and SACU's would be up by a further $\$ 4$ million annually - despite the assumed continuance of the EU moratorium.

It is instructive to focus also on the impacts on domestic food prices and quantities in the Rest of SADC in this third set of simulations. Table 6 reveals the extent to which domestic food production would be greater but by more in Sim $3 b$ where the Rest of SADC chooses not to adopt, and to ban GM imports, than in Sim 3c where it embraces the new technology. This is a case where the consequence of increasing agricultural protectionism dominate those from embracing the new technology. It is reflected also in the greater decline in rest of SADC's net imports of food in Sim 3b than $3 \mathrm{c}$, and in the increase in domestic food prices in Sim 3b compared with their decline in Sim 3c: farmers may be made better off in that region, but at the expense of domestic buyers of these foods and of the regional economy generally. ${ }^{14}$

Finally, consider a situation where GM varieties of rice and wheat that are nutritionally enhancing become available for adoption in Sub-Saharan Africa and elsewhere. Such varieties of second-generation GM technology promise to boost the health of the under-nourished and hence could raise the productivity of unskilled workers

\footnotetext{
${ }^{14}$ Lest anyone think that might be a desirable way to improve income distribution in the rest of SADC, recall that there will always be more efficient ways to re-distribute income than via trade policy (Corden 1997, Ch. 4).
} 
in SSA regardless of occupation, rather than just raise farm productivity as with firstgeneration GM varieties. Table 7 suggests this second-generation GM technology could have a major impact on poor people's welfare in SSA: if it were to raise all unskilled worker productivity in SSA by 2 percent, its estimated gain is 18 times as great as it would be if the GM varieties were just farm productivity enhancing (compare Sims $2 \mathrm{e}$ and 4a). And again, this startling result is independent of whether the EU maintains its current moratorium (compare Sims 4a and 4b).

The welfare results for all of these simulations are decomposed for the three SubSaharan African regions in Table 8, to show the extent to which they derive from productivity growth, from a change in the region's international terms of trade, or from a change in the economic efficiency of resource allocation in the region given its policy distortions. All three elements play a role in determining the overall welfare impacts, but the contribution of productivity growth dominates in all regions where GM adoption occurs - especially in the case of nutritionally enhancing varieties.

\section{Caveats}

As with all CGE modelling results, the above are subject to a number of qualifications. One has to do with the way consumer preferences are handled. The estimated market and welfare effects vary with the elasticities of substitution assumed between GM and non-GM varieties of a product. We have assumed those crosselasticities to be much lower in the EU and to a lesser extent Northeast Asia and Australia than in the current GM-adopting countries and in SSA and other developing countries. But because of the large size of those latter markets it turns out that varying the EU's 
elasticities makes little difference to relative prices and hence to the overall welfare results (see the sensitivity analysis reported in Anderson, Nielsen and Robinson, 2002).

Consumer welfare also depends on the imagined risk associated with consuming foods that may contain GMOs. Unfortunately we have no satisfactory way of evaluating what that loss of welfare would be for consumers who would like to avoid consuming foods containing GMOs but cannot if such foods are introduced into their marketplace without credible labelling. Since we have assumed that loss to be zero, we are overstating the gains from adopting this technology to that extent. An alternative way to cope with this issue is to introduce a cost of segregation and identity preservation. We did that implicitly by choosing conservative cost savings due to the new technology, saying they were net of any fees charged for segregation and identity preservation. According to Burton et al. (2002) such fees may be as high as 15 percent of farm gate price, which would make it unprofitable to market many GM varieties if that was a required condition of sale. Others suggest those costs could be miniscule - at least in developed economies on the grounds that such segregation is increasingly being demanded by consumers of many conventional foods anyway (e.g., different grades or varieties or attributes of each crop) so the marginal cost of expanding such systems to handle GM-ness would not be great, at least in countries that have already shown a willingness to pay for product differentiation.

The version of the GTAP database used in the above modelling does not include tariff preferences enjoyed by Africans exporting to the EU. This may be seen as causing a major underestimation in the potential gains in market access that Africa might enjoy from the EU moratorium on imports from GM-adopting countries. However, the degree 
of underestimation is likely to be small because of at least three practical features of preferences. One is that the EU's MFN tariffs on coarse grains and oilseeds are low which ensures the margin of preference is very low on those key products. Second, many exporters find that meeting the rules of origin to take advantage of preferences are so complicated that it is cheaper just to pay the MFN import duty. And third, where quantitative import restrictions are involved, at least some of any rent from the preference scheme is shared with the importer.

In all these simulations we assume for simplicity that there are no negative environmental risks net of positive environmental benefits associated with producing GM crops, and that there is no discounting and/or loss of market access abroad for other food products because of what GM adoption does for a country's generic reputation as a producer of 'clean, green, safe food'.

We have ignored the owners of intellectual property in GM varieties, and simply assumed the productivity advantage of GM varieties is net of the higher cost of GM seeds. In so far as that intellectual property is held by a firm in a country other than the GM-adopting country, then the gain from adoption is slightly overstated in the adopting country (and very slightly understated for the home regions of the relevant multinational biotech companies).

It is difficult to know how close to the mark is our assumed boost to unskilled labor productivity following adoption of second-generation GM varieties. But even if it is a gross exaggeration, discounting heavily the massive magnitude of the estimated welfare gain from adopting such varieties would still leave us with a large benefit particularly bearing in mind that developing countries are being offered this technology 
at no cost by its private sector developers, and that we have included no valuation of the non-pecuniary gain in well-being for sufferers of malnutrition. The cost of adapting the off-the-shelf technology to local conditions in Africa may well be non-trivial, however, and may require a better-functioning agricultural research system than has operated in the past four decades (as evidenced by Africa's relatively poor take-up of the previous green revolution - see Evenson and Gollin 2003).

\section{Concluding remarks}

From the viewpoint of Sub-Saharan Africa, the above results are positive, but are they very significant? After all, the final column in Tables 3 and 4 suggest the gains would be no more than 0.12 percent of GDP for SSA if all countries were to adopt firstgeneration GM varieties of major grains and oilseeds. However, that figure grossly understates the potential of this technology for Africa in several ways for at least four reasons.

First, these results apply only to four sets of crops, and so do not include the prospective farm productivity gains from GM varieties of other food staples yet to be developed.

Second, crops other than food also could gain from GM technologies, as the spectacular example of cotton is already starting to show (see FAO 2004, Ch 4).

Third, those welfare gains from first-generation, farm productivity-enhancing GM varieties could be multiplied - perhaps many fold, according to our fourth set of simulations above - if second-generation GM varieties such as golden rice were also to be embraced. 
Fourth, and perhaps most important, the above comparative static modeling assumes first-generation GM technology delivers just a one-off increase in farm productivity for that portion of a crop's area planted to GM varieties. But if/when the principle of GM crop production is accepted, there is likely to be an increase in the rate of farm productivity growth into the future. Second-generation GM varieties with additional health attributes such as those associated with golden rice also would be quicker in coming on stream the sooner additional countries embrace the technology.

In addition, if Sub-Saharan African countries were to adopt a policy response in the opposite direction - imposing bans on GM crop imports because the EU restricts imports from countries where GM varieties are available - our results in Table 5 suggest the domestic consumer loss net of that protectionism boost to Sub-Saharan African farmers would be more than the small gain derived from greater market access to the EU.

The stakes in this issue for Sub-Saharan Africa are thus high, with GM food technology potentially offering welfare gains that could alleviate poverty directly and perhaps substantially in those countries willing and able to adopt the new technology. African countries need to assess whether they share the food safety and environmental concerns of Europeans regarding GMOs. If not, their citizens in general, and their poor in particular, have much to gain from adopting GM crop varieties and especially secondgeneration ones. And, unlike for North America and Argentina where there is a heavy dependence on exports of maize and oilseeds, the welfare gains from GM crop adoption by Sub-Saharan African countries would not be jeopardized by rich countries banning imports of those crop products from the adopting countries. 


\section{References}

Anderson, K., L.A. Jackson and C.P. Nielsen (2004), 'GM Rice Adoption: Implications for Welfare and Poverty Alleviation', paper for the $7^{\text {th }}$ Annual Conference on Global Economic Analysis, Washington DC, 17-19 June.

Anderson, K. and C.P. Nielsen (2001), 'GMOs, Trade Policy, and Welfare in Rich and Poor Countries', Ch. 6 in Quantifying the Impact of Technical Barriers to Trade: Can it be Done? edited by K. Maskus and J. Wilson, Ann Arbor: University of Michigan Press.

Anderson, K., C.P. Nielsen and S. Robinson (2002), 'Estimating the Economic Effects of GMOs: the Importance of Policy Choices and Preferences,' Ch. 20 in Economic and Social Issues in Agricultural Biotechnology, edited by R.E. Evenson, V. Santaniello and D. Zilberman, London: CAB International.

Armington, P.A. (1969), 'A Theory of Demand for Products Distinguished by Place of Production', IMF Staff Papers 16: 159-178.

Beyer, P., S. Al-Babili, X. Ye, P. Lucca, P. Schaub, R. Welsch and I. Potrykus (2002), 'Golden Rice: Introducing the Beta-Carotene Biosynthesis Pathway into Rice Endosperm by Genetic Engineering to Defeat Vitamin A Deficiency', Journal of Nutrition 132: 506-10.

Bouis, H.E. (2002), 'Plant Breeding : A New Tool to Fight Micronutrient Malnutrition', Journal of Nutrition 132: 491S-494S.

Chen, S. and M. Ravallion (2004), 'How Have the World's Poorest Fared Since the Early 1980s?' mimeo, World Bank, Washington DC, April. Downloadable at www.worldbank.org/research/povmonitor/ 
Conway, G. (2003), 'From the Green Revolution to the Biotechnology Revolution: Food for Poor People in the $21^{\text {st }}$ Century', paper presented at the Directors' Forum, Woodrow Wilson International Center for Scholars, 12 March.

Corden, W.M. (1997), Trade Policy and Economic Welfare, (revised edition), Oxford: Clarendon Press.

Diamond, J. (1998), Guns, Germs and Steel: A Short History of Everybody for the Last 13,000 Years, London: Vintage.

Dimaranan, B.V. and R.A. McDougall (eds.) (2002), Global Trade, Assistance, and Production: The GTAP 5 Data Base, West Lafayette: Center for Global Trade Analysis, Purdue University.

Evenson, R.E. and D. Gollin (2003), 'Assessing the Impact of the Green Revolution, 1960-2000', Science 300: 758-62, May 2.

FAO (2004), The State of Food and Agriculture 2004, Rome: United Nations Food and Agriculture Organisation.

Harrison, W.J., J.M. Horridge and K.R. Pearson (1996), 'Decomposing Simulation Results with Respect to Exogenous Shocks', Working Paper No. IP-73, Centre of Policy Studies and the IMPACT Project, Monash University, May.

Harrison, W.J. and K.R. Pearson (1996), 'Computing Solutions for Large General Equilibrium Models Using GEMPACK', Computational Economics 9: 83-172.

Hertel, Thomas W. (ed.) (1997), Global Trade Analysis: Modeling and Applications, Cambridge and New York: Cambridge University Press.

Hossain, F., C.E. Pray, Y. Lu, J. Huang, C. Fan and R. Hu (2004), 'Genetically Modified Cotton and Farmers' Health in China', International Journal of Occupational and Environmental Health 10: 307-14. 
Huang, J., R. Hu, H. van Meijl and F. van Tongeren (2004), 'Biotechnology Boosts to Crop Productivity in China: Trade and Welfare Implications,' Journal of Development Economics 74 (forthcoming).

Jackson, L.A. and K. Anderson (2003), 'Why Are United States and EU Policies Toward GMOs So Different?' AgBioForum 6(3): 96-100.

Lapan, H.E. and G.C. Moschini (2004), 'Innovation and Trade with Endogenous Market Failure: The Case of Genetically Modified Products', American Journal of Agricultural Economics 86(3): 634-48, August.

Marra, M., P. Pardey and J. Alston (2002), 'The Payoffs to Agricultural Biotechnology: An Assessment of the Evidence', AgBioForum 5(2): 43-50. Downloadable at http://www.agbioforum.org/v5n2/v5n2a02-marra.pdf

van Meijl, H. and F. van Tongeren (2002), 'International Diffusion of Gains from Biotechnology and the European Union's Common Agricultural Policy,' Paper presented at the 5th Annual Conference on Global Economic Analysis, Taipei, Taiwan.

Nielsen, C.P. and K. Anderson (2001), 'Global Market Effects of European Responses to Genetically Modified Organisms', Weltwertschaftliches Archiv 137(2): 320-46, June.

Pray, C.E., P. Bengali and B. Ramaswami (2004), 'Costs and Benefits of Biosafety Regulation in India: A Preliminary Assessment', Paper presented at the $8^{\text {th }}$ ICABR Conference, Ravello (Italy), 8-11 July.

Pray, C.E., J. Huang, D. Ma and F. Qiao (2003), 'Impact of Bt Cotton in China', World Development 29(5): 813-25. 
Qaim, M. and D. Zilberman (2003), 'Yield Effects of Genetically Modified Crops in Developing Countries', Science 299: 900-02.

USDA (2001), Agricultural Income and Finance Outlook, ERS Report AIS-77, Washington, DC: US Department of Agriculture, 25 September.

Welch, R.M. (2002), 'Breeding Strategies for Biofortified Staple Plant Foods to Reduce Micronutrient Malnutrition Globally', Journal of Nutrition 132: 495S-499S.

Ye, X., S. Al-Babili, A. Kolti, J. Zhang, P. Lucca, P. Beyer and I. Potrykus (2000), 'Engineering the Provitamin A (Beta-Carotene) Biosynthetic Pathway into (Carotenoid-Free) Rice Endosperm', Science 287: 303-05.

Zimmermann, R. and M. Qaim (2002), 'Projecting the Benefits of Golden Rice in the Philippines', ZEF Discussion Paper No. 51, Bonn: Center for Development Research, September. 
Table 1: Assumed impact of adoption of first-generation GM crop technology on factor productivity for GM varieties relative to current non-GM varieties, by sector

(percent difference)

\begin{tabular}{lcccc} 
& $\begin{array}{c}\text { GM } \\
\text { coarse } \\
\text { grains }\end{array}$ & $\begin{array}{c}\text { GM } \\
\text { oilseeds }\end{array}$ & $\begin{array}{c}\text { GM } \\
\text { wheat }\end{array}$ & $\begin{array}{c}\text { GM rice } \\
\text { (non- } \\
\text { golden) }\end{array}$ \\
\hline Land & 7.5 & 6 & 5 & 5 \\
Skilled labor & 7.5 & 6 & 5 & 5 \\
Unskilled labor & 7.5 & 6 & 5 & 5 \\
Capital & 7.5 & 6 & 5 & 5 \\
Natural Resources & 7.5 & 6 & 5 & 5
\end{tabular}

Source: Authors' assumptions, based on literature reviews by Marra, Pardey and Alston (2002), Qaim and Zilberman (2003), Huang, Hu, van Meijl and van Tongeren (2004) and FAO (2004). 


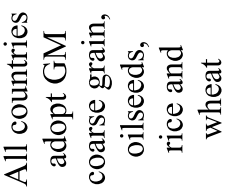

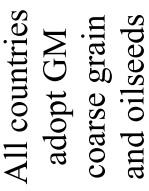

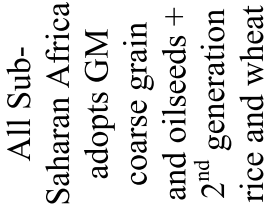

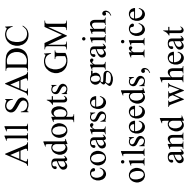

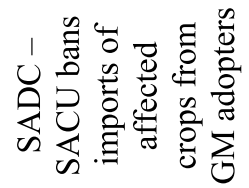

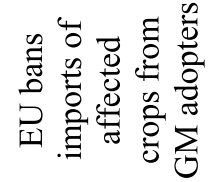

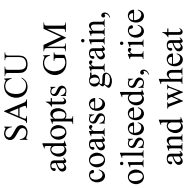

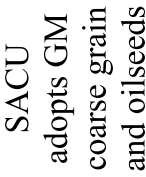

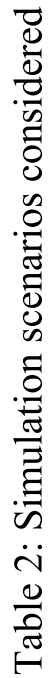

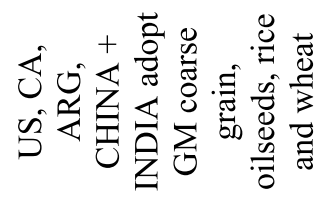

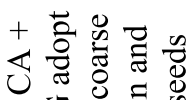

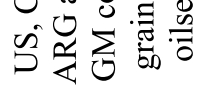

$x \times x$

$x x x x \quad x x \quad x x$

$x x$

$x$

$x x$

$x x \quad x$

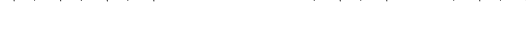

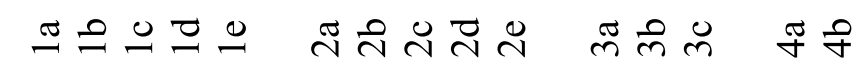


Table 3: Estimated economic welfare effects of GM coarse grain and oilseed adoption by various countries (US\$ million per year)

\begin{tabular}{|c|c|c|c|c|c|c|}
\hline & \multicolumn{2}{|c|}{ US, CAN and ARG adopt } & \multicolumn{2}{|c|}{$\begin{array}{c}\text { US, CAN, ARG + SACU } \\
\text { adopt }\end{array}$} & \multicolumn{2}{|c|}{ All countries adopt } \\
\hline & $\begin{array}{r}\text { Without } \\
\text { policy } \\
\text { response }\end{array}$ & $\begin{array}{r}\text { With EU } \\
\text { moratorium }\end{array}$ & $\begin{array}{r}\text { Without } \\
\text { policy } \\
\text { response }\end{array}$ & $\begin{array}{r}\text { With EU } \\
\text { moratorium }\end{array}$ & $\begin{array}{r}\text { Without } \\
\text { policy } \\
\text { response }\end{array}$ & \\
\hline & Sim $1 a$ & Sim $1 b$ & $\operatorname{Sim} 1 c$ & Sim 1d & Sim 1e & $\begin{array}{r}E V \text { as } \% \\
\text { of } G D P \\
(\operatorname{sim} 1 e)\end{array}$ \\
\hline $\begin{array}{l}\text { Change in econ } \\
\text { (equivalent varia }\end{array}$ & & & & & & \\
\hline SACU & 3 & 7 & 9 & 5 & 9 & 0.01 \\
\hline Rest of SADC & 0 & 2 & 0 & 3 & 18 & 0.04 \\
\hline Rest of SSA & -2 & 12 & -1 & 14 & 42 & 0.03 \\
\hline Argentina & 312 & 247 & 312 & 246 & 287 & 0.11 \\
\hline Canada & 72 & 7 & 72 & 7 & 65 & 0.01 \\
\hline US & 939 & 628 & 939 & 627 & 897 & 0.01 \\
\hline EU-15 & 267 & -3145 & 269 & -3179 & 595 & 0.01 \\
\hline Rest of World & 700 & 1027 & 225 & 1001 & 2204 & 0.02 \\
\hline WORLD & 2290 & -1243 & 2300 & -1276 & 4047 & 0.013 \\
\hline
\end{tabular}

Source: Authors' GTAP model simulation results 
Table 4: Estimated economic welfare effects of GM coarse grain, oilseed, rice and wheat adoption by various countries

(equivalent variation in income, US\$ million)

\begin{tabular}{|c|c|c|c|c|c|c|}
\hline & \multicolumn{2}{|c|}{$\begin{array}{l}\text { US, CAN, ARG, CHN } \\
\text { and IND adopt }\end{array}$} & \multicolumn{2}{|c|}{$\begin{array}{l}\text { US, CAN, ARG, CHN, and } \\
\text { IND + SACU adopt }\end{array}$} & \multicolumn{2}{|c|}{ All countries adopt } \\
\hline & $\begin{array}{r}\text { Without } \\
\text { policy } \\
\text { response }\end{array}$ & $\begin{array}{l}\text { With EU } \\
\text { moratorium }\end{array}$ & $\begin{array}{r}\text { Without } \\
\text { policy } \\
\text { response }\end{array}$ & $\begin{array}{l}\text { With EU } \\
\text { moratorium }\end{array}$ & $\begin{array}{r}\text { Without } \\
\text { policy } \\
\text { response }\end{array}$ & \\
\hline & $\operatorname{Sim} 2 a$ & $\operatorname{Sim} 2 b$ & $\operatorname{Sim} 2 c$ & $\operatorname{Sim} 2 d$ & $\operatorname{Sim} 2 e$ & $\begin{array}{c}E V \text { as \% } \\
\text { of } G D P \\
(\operatorname{sim} 2 e)\end{array}$ \\
\hline $\begin{array}{l}\text { Change in econ } \\
\text { (equivalent varia }\end{array}$ & \$m) & & & & & \\
\hline SACU & 7 & 11 & 13 & 10 & 15 & 0.01 \\
\hline Rest of SADC & 0 & 4 & 0 & 4 & 22 & 0.05 \\
\hline Rest of SSA & 5 & 23 & 6 & 24 & 165 & 0.12 \\
\hline Argentina & 350 & 285 & 350 & 285 & 312 & 0.12 \\
\hline Canada & 83 & -23 & 83 & -23 & 63 & 0.01 \\
\hline US & 1045 & 754 & 1045 & 754 & 1041 & 0.01 \\
\hline China & 841 & 833 & 841 & 832 & 899 & 0.25 \\
\hline India & 669 & 654 & 669 & 654 & 669 & 0.14 \\
\hline EU-15 & 355 & -4717 & 358 & -4754 & 810 & 0.01 \\
\hline Rest of World & 964 & 1322 & 953 & 1285 & 3509 & 0.03 \\
\hline WORLD & 4308 & -892 & 4319 & -928 & 7506 & 0.024 \\
\hline
\end{tabular}

Source: Authors' GTAP model simulation results 
Table 5: Estimated economic welfare effects of GM adoption with SADC other than SACU either banning or adopting GM varieties

\begin{tabular}{|c|c|c|c|}
\hline & $\begin{array}{c}\text { US, CAN, ARG and } \\
\text { SACU adopt GM } \\
\text { coarse grains and } \\
\text { oilseeds }\end{array}$ & $\begin{array}{c}\text { US, CAN, ARG, } \\
\text { CHN, IND and } \\
\text { SACU adopt GM } \\
\text { coarse grains, } \\
\text { oilseeds, rice and } \\
\text { wheat }\end{array}$ & $\begin{array}{c}\text { As for } 3 b+\text { Rest } \\
\text { of SADC adopts } \\
\text { same GM } \\
\text { commodities }\end{array}$ \\
\hline & $\begin{array}{c}\text { With EU and SADC } \\
\text { (excl SACU) } \\
\text { moratoria }\end{array}$ & $\begin{array}{c}\text { With EU and SADC } \\
\text { (excl SACU) } \\
\text { moratoria }\end{array}$ & $\begin{array}{l}\text { With EU } \\
\text { moratorium }\end{array}$ \\
\hline & Sim $3 a$ & $\operatorname{Sim} 3 b$ & $\operatorname{Sim} 3 c$ \\
\hline \multicolumn{4}{|c|}{$\begin{array}{l}\text { Change in economic welfare } \\
\text { (equivalent variation in income, } \$ \mathrm{~m} \text { ) }\end{array}$} \\
\hline SACU & 2 & 6 & 10 \\
\hline Rest of SADC & -2 & -10 & 26 \\
\hline Rest of SSA & 14 & 25 & 25 \\
\hline Argentina & 246 & 284 & 285 \\
\hline Canada & 7 & -24 & -23 \\
\hline US & 626 & 756 & 754 \\
\hline China & 111 & 833 & 833 \\
\hline India & 3 & 654 & 654 \\
\hline EU-15 & -3181 & -4760 & -4750 \\
\hline Rest of World & 889 & 1290 & 1286 \\
\hline WORLD & -1287 & -946 & -900 \\
\hline
\end{tabular}

Source: Authors' GTAP model simulation results 
Table 6: Trade and domestic production, price and trade impacts in SADC other than SACU (Rest of SADC) of GM adoption, with Rest of SADC either banning or also adopting GM varieties

(percentage changes)

\begin{tabular}{|c|c|c|}
\hline & $\begin{array}{c}\text { US, CAN, ARG, CHN, IND, } \\
\text { SACU adopt GM coarse } \\
\text { grains, oilseeds, rice and } \\
\text { wheat }\end{array}$ & $\begin{array}{l}\text { US, CAN, ARG, CHN, IND, } \\
\text { SACU adopt GM coarse } \\
\text { grains, oilseeds, rice and } \\
\text { wheat }+ \text { Rest of SADC adopts }\end{array}$ \\
\hline & $\begin{array}{c}\text { With EU and Rest of SADC } \\
\text { Moratoria }\end{array}$ & $\begin{array}{l}\text { With just EU } \\
\text { Moratorium }\end{array}$ \\
\hline & Sim $3 b$ & Sim $3 c$ \\
\hline \multicolumn{3}{|l|}{ Production } \\
\hline Coarse grains & 1.0 & 0.4 \\
\hline Oilseeds & 5.8 & 1.8 \\
\hline Rice & 1.5 & 0.9 \\
\hline Wheat & 15.6 & 0.7 \\
\hline Meat & 0.0 & 0.3 \\
\hline \multicolumn{3}{|c|}{ Domestic market prices } \\
\hline Coarse grains & 0.3 & -0.8 \\
\hline Oilseeds & 0.3 & -1.2 \\
\hline Rice & 0.3 & -1.0 \\
\hline Wheat & 0.4 & -0.3 \\
\hline Meat & 0.2 & 0.0 \\
\hline \multicolumn{3}{|l|}{ Imports } \\
\hline Coarse grains & -25.7 & -2.2 \\
\hline Oilseeds & -52.5 & -0.6 \\
\hline Rice & -6.9 & -4.1 \\
\hline Wheat & -21.2 & -0.2 \\
\hline Meat & -0.4 & -0.9 \\
\hline \multicolumn{3}{|l|}{ Exports } \\
\hline Coarse grains & 1.2 & 4.2 \\
\hline Oilseeds & 9.2 & 12.0 \\
\hline Rice & 7.0 & 11.7 \\
\hline Wheat & 1.7 & -0.3 \\
\hline Meat & 0.6 & 1.4 \\
\hline
\end{tabular}

Source: Authors' GTAP model simulation results. 
Table 7: Estimated economic welfare effects of GM crop adoption with Sub-Saharan Africa's being second-generation, nutritionally enhanced rice and wheat

(US\$ million per year)

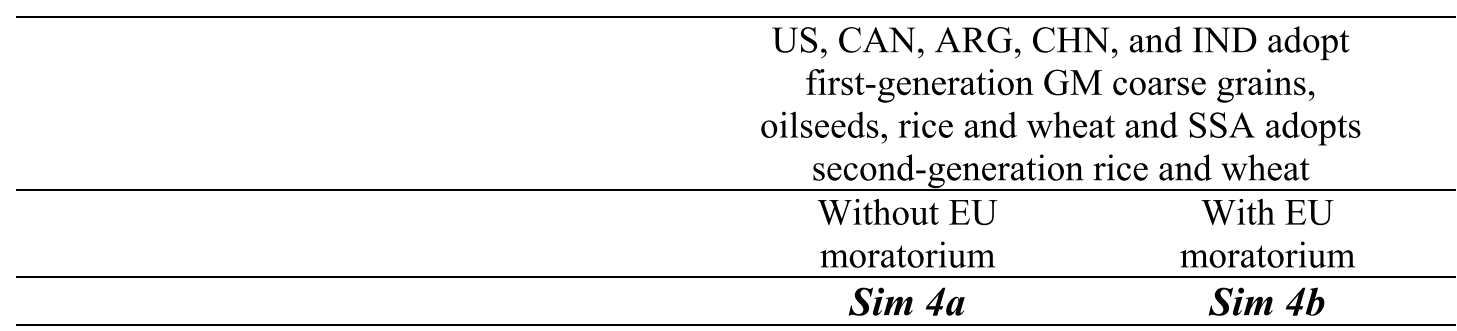

Change in economic welfare

(equivalent variation in income, $\$ \mathrm{~m}$ )

SACU

1786

1789

Rest of SADC

403

407

Rest of SSA

1421

1439

Source: Authors' GTAP model simulation results 
Table 8: Decomposition of national economic welfare effects due to GM adoption under various simulations ${ }^{\mathrm{a}}$

(equivalent variation in income, US\$ million)

\begin{tabular}{rrrr}
$\begin{array}{r}\text { Allocative } \\
\text { efficiency } \\
\text { impact }\end{array}$ & $\begin{array}{r}\text { Terms of } \\
\text { trade } \\
\text { impact }\end{array}$ & $\begin{array}{r}\text { Productivity } \\
\text { growth } \\
\text { impact }\end{array}$ & $\begin{array}{r}\text { Total } \\
\text { impact }\end{array}$ \\
\hline
\end{tabular}

\section{SACU}

Sim $1 a$

Sim $1 b$

Sim $1 c$

Sim 1d

Sim $1 e$

$\operatorname{Sim} 2^{a}$

$\operatorname{Sim} 2 b$

$\operatorname{Sim} 2 c$

Sim $2 d$

Sim $2 e$

Sim $3 a$

Sim $3 b$

Sim $3 c$

Sim $4 a$

Sim $4 b$

$\begin{array}{rrrr}3 & 1 & 0 & 3 \\ 2 & 5 & 0 & 7 \\ 2 & 0 & 7 & 9 \\ -2 & -1 & 7 & 5 \\ 3 & 0 & 7 & 9 \\ 4 & 3 & 0 & 7 \\ 3 & 9 & 0 & 11 \\ 3 & 2 & 9 & 13 \\ -1 & 3 & 8 & 10 \\ 4 & 3 & 8 & 15 \\ -3 & -3 & 7 & 2 \\ -3 & 1 & 8 & 6 \\ -1 & 3 & 8 & 10 \\ 216 & 22 & 1549 & 1786 \\ 215 & 28 & 1549 & 1789\end{array}$

\section{Rest of SADC}

Sim 1a

Sim $1 b$

Sim 1c

Sim 1d

Sim 1 e

Sim $2 a$

$\operatorname{Sim} 2 b$

$\operatorname{Sim} 2 c$

Sim 2d

Sim $2 e$

$\operatorname{Sim} 3^{a}$

Sim $3 b$

$\operatorname{Sim} 3 c$

Sim $4 a$

Sim $4 b$

Sim 1a

Sim $1 b$

Sim 1c

Sim 1d

Sim 1e

Sim $2 a$

$\operatorname{Sim} 2 b$

$\operatorname{Sim} 2 c$

Sim 2d 


\begin{tabular}{rrrr}
$\begin{array}{r}\text { Allocative } \\
\text { efficiency }\end{array}$ & $\begin{array}{rrr}\text { Terms of } \\
\text { trade }\end{array}$ & $\begin{array}{rrr}\text { Productivity } \\
\text { growth }\end{array}$ & $\begin{array}{r}\text { Total } \\
\text { impact }\end{array}$ \\
\hline
\end{tabular}

\section{Rest of SADC (continuation)}

Sim $2 e$

Sim $3 a$

$\operatorname{Sim} 3 b$

$\operatorname{Sim} 3 c$

$\operatorname{Sim} 4 a$

$\operatorname{Sim} 4 b$

$\begin{array}{rrrr}7 & -5 & 163 & 165 \\ 2 & 10 & 0 & 14 \\ 5 & 17 & 0 & 25 \\ 6 & 17 & 0 & 25 \\ -11 & -396 & 1887 & 1421 \\ -8 & -383 & 1888 & 1439\end{array}$

a See the previous four tables for the descriptions of each of the simulations. The welfare decomposition follows Harrison, Horridge and Pearson (1999).

Source: Authors' GTAP model simulation results 